\title{
The effect of menstrual cycle phase on multiple performance test parameters
}

\section{Menstrual siklus fazının çoklu performans test parametrelerine etkisi}

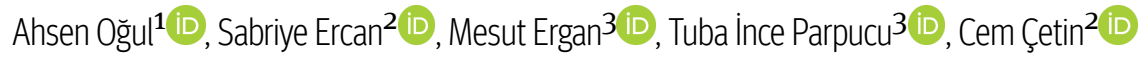 \\ ${ }^{1}$ Sports Medicine Section, Gazi Yaşargil Training and Research Hospital, Diyarbakır, Turkey \\ ${ }^{2}$ Sports Medicine Department, Faculty of Medicine, Süleyman Demirel University, Isparta, Turkey \\ 3 Physiotherapy and Rehabilitation Department, Faculty of Health Sciences, Süleyman Demirel University, Isparta, Turkey
}

\section{ABSTRACT}

Objective: To determine changes in flexibility, dynamic balance, agility, vertical jump, aerobic capacity, anaerobic capacity, and muscle strength performances in women in the early follicular and midluteal phases of the menstrual cycle.

Material and Methods: The study included eumenorrheic women over 18 years of age. Ovulation was detected using LH urine kits. Physical activity levels were determined using the "International Physical Activity Questionnaire-Short Form". Flexibility was evaluated with the sit-and-reach test, dynamic balance with the $Y$ balance test, agility with the hexagon agility test, anaerobic power with the vertical jump test, aerobic capacity with the 20-meter shuttle run test, anaerobic capacity with the Wingate test, and muscle strength with an isokinetic dynamometer.

Results: Twenty women participated in the study. The average age was $22.4 \pm 0.9$ years, and the average level of physical activity was $1162.2 \pm$ 189.1 MET-min/week. The average menstrual cycle was $30.3 \pm 0.5$ days. The 'minimum power' value in Wingate test was higher during the midluteal phase compared with the follicular phase $(p=0.048)$. The remaining parameters were not statistically different for the two menstrual phases ( $p>0.05)$.

Conclusion: We conclude that different phases of the menstrual cycle affect performance parameters minimally and do not cause a statistically significant difference. Nevertheless, instead of establishing these changes as 'clinically non-significant', each athlete should be evaluated on an individual basis to develop individual training programs by taking into account the phases of the menstrual cycle.

Keywords: Female athlete, menstrual cycle, sports performance

$\underline{\text { öz }}$

Amaç: Kadınlarda erken foliküler ve midluteal fazda esneklik, dinamik denge, çeviklik, dikey sıçrama, aerobik kapasite, anaerobik kapasite ve kas kuvveti performanslarında meydana gelen değişimleri saptamak amaçlandı.

Gereç ve Yöntem: Araşıımaya 18 yaş üzeri ömenoreik kadınlar alındı. Araştırmaya katılan bireylerde ovülasyon luteinize edici hormon idrar kiti ile saptandı. Araştırmada fiziksel aktivite düzeyleri 'Uluslararası Fiziksel Aktivite Anketi-Kısa Formu' ile belirlendi. Katılımcıların esneklikleri otur eriş testi, dinamik dengeleri Y balans testi, çeviklikleri altıgen koordinasyon testi, anaerobik güç serbest dikey sıçrama testi, aerobik kapasite 20 metre mekik koşu testi, anaerobik kapasite Wingate testi, kas kuvveti ise izokinetik dinamometre ile değerlendirildi.

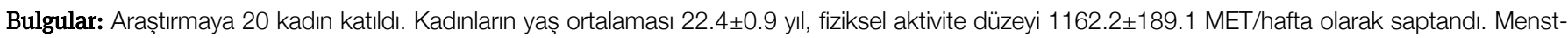

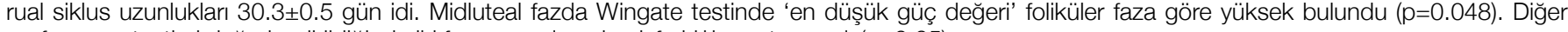
performans testleri değerlendirildiğinde iki faz arasında anlamlı farklılı saptanmadı ( $p>0.05)$.

Sonuç: Menstrual siklusun fazlarına göre performans değișikliklerinin minimal düzeyde olduğu ve istatistiksel olarak anlamlı fark oluşturmadığı saptandı. Bu performans değişikliklerine 'Klinik olarak anlamlı değildir' demek yerine her sporcunun kendi özelinde değerlendirilmeli ve menstrual siklus fazına göre bireysel antrenman programlarının düzenlenmesi önerilmelidir.

Anahtar Sözcükler: Kadın sporcu, menstrual siklus, sportif performans

\section{INTRODUCTION}

Women are increasingly participating in sports activities of all kinds, both amateur and professional (1). For instance, women made up $26 \%$ of all athletes who participated in the 1988 Seoul Olympics and 45\% in the 2016 Rio Olympics. This number is expected to increase to $49 \%$ in the 2021 Tokyo Olympics (2).

With increasing female participation in sports, gender differences in exercise performances and development have become of interest. Anatomical, physiological, endocrinological, and psychological factors could explain the differences between male and female athletes' physical performances, and menstrual cycle is especially prominent (3). 
The menstrual cycle is divided into three phases: the early follicular phase with low estrogen and progesterone, the ovulatory phase with high estrogen and low progesterone, and the midluteal phase with high estrogen and high progesterone (4). Serum luteinizing hormone (LH), follicle-stimulating hormone (FSH), estradiol (E2), and progesterone (Prog) concentrations fluctuate over the menstrual cycle, and androstenedione and testosterone levels peak immediately before and during ovulation (5). These hormones primarily regulate the reproductive cycle but also impact various physiological functions, which may translate into altered physical performance (6).

Estrogen has anabolic influence on skeletal muscles and is argued to improve endurance by altering carbohydrate, fat and protein metabolisms. Progesterone, on the other hand, has anti-estrogenic effects. For type-1 muscle fibers, estrogen increases glucose uptake and availability during shortterm exercise, while the opposite is observed with progesterone (6).

Studies concerning the effect of menstrual cycle on exercise performance have yielded various and inconsistent results. Clarifying the changes in performance according to the phases of the menstrual cycle, and organizing athlete training programs according to the effects, including them in acute/chronic workload calculations may be effective in protecting female athletes from injuries. For this purpose, it was aimed to examine the effects of menstrual cycle phases on physical fitness parameters. The hypothesis of the research is that the effect of phase changes on physical fitness components, flexibility, and time from peak effort to relaxation would be in the direction of pleasure.

\section{MATERIALS and METHODS}

After the study was approved by the local ethics committee (date 29/11/2019 number 323), voluntary and healthy women who conformed to the inclusion criteria were recruited. The study included healthy women with regular normal-length (21-35 days) menstrual cycles in the last six months. The exclusion criteria were as follows: oligo-, polyor amenorrhea or metromenorrhagia, use of Depo-Provera, Norplant or intrauterine medication in the last 12 months, oral contraceptive use or hormone therapy in the last three months, endometriosis, polycystic ovary syndrome, uterine fibroids, body mass index $<18 \mathrm{~kg} / \mathrm{m}^{2}$ or $>35 \mathrm{~kg} / \mathrm{m}^{2}$, smoking, alcohol or illegal drug use, a calorie-restricted diet, pregnancy, musculoskeletal disease in the last six months, heart disease, inflammatory or autoimmune diseases, diabetes, any endocrine disorder (e.g. hypo-/hyperthyroidism, etc.), anemia, or using medication or nutritional supplements.
Physical activity was evaluated using the "International Physical Activity Questionnaire-Short Form" (IPAQ-SF) (7). Participants' menstrual data (cycle length, date of the last period, etc.) were recorded. Cross-randomization was performed in multiple performance tests.

Determining the phase of menstrual cycle: The early follicular phase was estimated to be cycle days 2-5, and the midluteal phase was defined as days 4-8 after ovulation. Ovulation was determined using home LH ovulation cassette tests (Laboquick, Izmir, Turkey) that can detect LH hormone in urine just in minutes with a sensitivity of $30 \mathrm{mIU} / \mathrm{ml}$ (8).Participants were provided with five disposable cassettes. Starting from two days before estimated ovulation, LH levels were tested using urine samples retrieved after 10 AM for five days. The 24-hour period after a positive test was accepted as the day of ovulation (9).

Determining body composition: Height, body weight (SECA 700, Germany), waist circumference, and hip circumference were measured (10). Four skinfold measurements (biceps, triceps, subscapular, and suprailiac) were made using a caliper (Baseline ${ }^{\circledR}$ Skinfold Caliper, 12-1110, United States). Body fat ratio was calculated by averaging the results as described by Yuhasz (11) and Siri (12).

Before the testing session started, the participants were allowed a 5-min warm up at light intensity (less than $50 \mathrm{~W}$ ). Tests were performed in the order of Y-balance test, $20-\mathrm{m}$ shuttle run test, vertical jump, hexagon agility test, isokinetic muscle test, sit-and-reach test and Wingate anaerobic capacity test. Between each test, the participants rested for 15 minutes, and for 30 minutes before the isokinetic- and Wingate tests. Participants had access to water and carbohydrate compounds during their rest periods. They were verbally motivated during the tests. All measurement procedures were applied in the same way in both phases.

Sit-and-reach test: It was used to assess flexibility by doing as described in the literature (13). The test was repeated twice and the average value was recorded.

$Y$ balance test: It was used to assess dynamic balance by doing as described in the literature (14). The test was repeated three times in each direction, and the highest score was recorded. Total score was calculated using the following formula:

$[($ anterior + posteromedial + posterolateral) $/(3 \times$ lower limb length) $\times 100](14)$.

Hexagon agility test: It was used to assess agility by doing as described in the literature (15). After 5-min rest, the test was repeated and the average of the two results was recorded. 
Vertical jump test: The test was repeated three times and vertical jump distances were recorded and averaged. Anaerobic power was calculated using the formula described by Lewis (16).

20-m shuttle run test. To determine endurance, participants were asked to run a 20-m distance back and forth until exhaustion (17). The test was terminated when the participants were 'beeped' twice in a row, when they could not catch the run, or stated that they were exhausted.

Wingate anaerobic capacity test: The participants were asked to perform for 30 seconds against external resistance of $7.5 \%$ of their body weight on a cycle ergometer (Wingate Test System 894E) (18).

Isokinetic muscle test: Before starting the test, the participants were allowed two tries at $60^{\circ} / \mathrm{s}$ and $180^{\circ} \mathrm{s}$ for adaptation. For the determination of muscle strength, the isokinetic test protocol (Isoforce, Germany) (19) was applied to both knees five times at an angular velocity of $60^{\circ} / \mathrm{s}$ and 20 times at an angular velocity of $180 \%$ s.

\section{Statistical analysis}

Data were analyzed using the SPSS v23 software package. Data were evaluated using frequency and descriptive statistical analysis. Upon determining normal distribution of data with the Shapiro Wilk test, the Wilcoxon test was preferred. The differences between the measurements were investigated using the Wilcoxon Signed Rank test. Statistical significance was considered at 0.05 . The results were presented as median \pm standard error.

\section{RESULTS}

A total of 128 women presented to the clinic between December 2019-2020. One hundred eight women were excluded due to reasons given in Figure 1. Twenty women aged $22.4 \pm 0.9$ years were finally enrolled. The average level of physical activity was $1162.2 \pm 189.1 \mathrm{MET}$-min/week. The average menstrual cycle was $30.3 \pm 0.5$ days.

Average body mass index was $20.7 \pm 0.3 \mathrm{~kg} / \mathrm{m}^{2}$. Body fat ratios were calculated as $(13.3 \pm 0.4)$ and $(18.3 \pm 0.7) \%$ according to Yuhazs and Siri formulas, respectively. The mean body fat ratio calculated by averaging these two results was $(15.0 \pm 0.5) \%$. Mean waist circumference was $70.2 \pm 1.3 \mathrm{~cm}$ and mean hip circumference was $94 \cdot 1 \pm 1.2 \mathrm{~cm}$.

Among the multiple performance tests of physical fitness parameters, menstrual cycle phase was not found to be statistically ( $p>0.05$ ) (Table 1-3). We found that only 'minimum power' in the Wingate test was significantly higher in the midluteal phase $(\mathrm{p}=0.048)$ (Table 2 ).

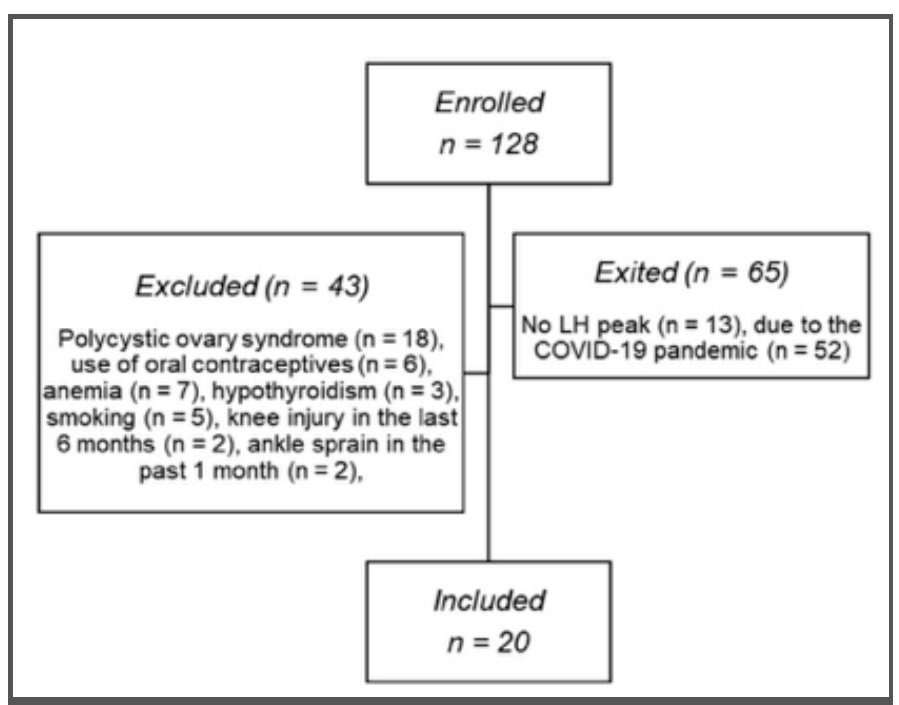

Figure 1. Study flow chart

Table 1. Flexibility, dynamic balance, agility, and vertical jump findings

\begin{tabular}{lccc}
\multicolumn{1}{c}{ Test/phase } & Follicular phase & Luteal phase & $\mathbf{p}$ \\
Sit-and-reach test $(\mathrm{cm})$ & $25.9 \pm 1.6$ & $25.2 \pm 1.9$ & 0.587 \\
$\begin{array}{l}\text { Y Balance total score }(\mathrm{cm}) \\
\quad\end{array}$ & $101.7 \pm 1.7$ & $103.9 \pm 2.3$ & 0.191 \\
$\quad$ Right & $102.3 \pm 1.8$ & $103.4 \pm 2.5$ & 0.433 \\
$\quad$ Left & $29.5 \pm 1.9$ & $28.2 \pm 1.5$ & 0.179 \\
Hexagon agility test $(\mathrm{s})$ & $29.5 \pm 0.8$ & $29.5 \pm 1.1$ & 0.911 \\
Vertical jump distance $(\mathrm{cm})$ & & \\
Results as median \pm standard error $(\mathrm{Med} \pm \mathrm{SE}) ; \mathrm{n}=20$ & &
\end{tabular}

Table 2. Aerobic capacity, anaerobic power and capacity findings

\begin{tabular}{|c|c|c|c|}
\hline Test/phase & $\begin{array}{l}\text { Follicular } \\
\text { phase }\end{array}$ & $\begin{array}{l}\text { Luteal } \\
\text { phase }\end{array}$ & $\mathbf{p}$ \\
\hline $\mathrm{VO}_{2} \max (\mathrm{ml} / \mathrm{min} / \mathrm{kg})$ & $23.7 \pm 0.3$ & $23.8 \pm 0.3$ & 0.507 \\
\hline Anaerobic power(kgm/s) & $89.4 \pm 1.4$ & $89.1 \pm 1.8$ & 0.911 \\
\hline \multicolumn{4}{|l|}{$\begin{array}{l}\text { Wingate anaerobic capacity test } \\
(\mathrm{W} / \mathrm{kg})\end{array}$} \\
\hline Peak power & $8.3 \pm 0.5$ & $7.9 \pm 0.3$ & 0.575 \\
\hline Average power & $4.2 \pm 0.2$ & $4.5 \pm 0.2$ & 0.086 \\
\hline Minimum power & $2.7 \pm 0.2$ & $3.1 \pm 0.2$ & $0.048^{*}$ \\
\hline Power drop & $5.6 \pm 0.5$ & $5.0 \pm 0.4$ & 0.287 \\
\hline
\end{tabular}

\begin{tabular}{|c|c|c|c|c|}
\hline \multirow{8}{*}{ 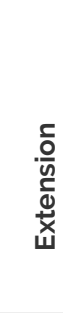 } & Test/phase & $\begin{array}{l}\text { Follicular } \\
\text { phase }\end{array}$ & $\begin{array}{l}\text { Luteal } \\
\text { phase }\end{array}$ & $p$ \\
\hline & PT (Nm) & $112.1 \pm 2.6$ & $110.1 \pm 2.7$ & 0.586 \\
\hline & $\mathbf{P T} / \mathbf{B W}(\mathrm{Nm} / \mathrm{kg})$ & $1.90 \pm 0.01$ & $1.90 \pm 0.06$ & 0.742 \\
\hline & Position of peak torque $\left(^{\circ}\right)$ & $45.6 \pm 1.5$ & $45.8 \pm 1.2$ & 0.856 \\
\hline & Time to peak torque (s) & $0.70 \pm 0.02$ & $0.70 \pm 0.02$ & 0.426 \\
\hline & $\begin{array}{l}\text { Time from peak to } \\
\text { relaxation }(\mathrm{s})\end{array}$ & $0.80 \pm 0.03$ & $0.80 \pm 0.03$ & 0.390 \\
\hline & IPT (Nm) & $67.8 \pm 1.9$ & $68.3 \pm 1.7$ & 0.371 \\
\hline & TW $(J)$ & $940.7 \pm 41.9$ & $959.6 \pm 37.2$ & 0.428 \\
\hline \multirow{7}{*}{$\frac{\text { 음 }}{\frac{0}{x}}$} & PT (Nm) & $40.6 \pm 2.2$ & $42.7 \pm 1.9$ & 0.125 \\
\hline & PT/BW(Nm/kg) & $0.70 \pm 0.05$ & $0.80 \pm 0.04$ & 0.112 \\
\hline & Position of peak torque $\left(^{\circ}\right)$ & $34.5 \pm 2.3$ & $34.1 \pm 2.0$ & 0.748 \\
\hline & Time to peak torque (s) & $0.50 \pm 0.03$ & $0.50 \pm 0.03$ & 0.798 \\
\hline & $\begin{array}{l}\text { Time from peak to } \\
\text { relaxation (s) }\end{array}$ & $0.70 \pm 0.04$ & $0.70 \pm 0.04$ & 0.920 \\
\hline & IPT (Nm) & $32.3 \pm 1.7$ & $32.6 \pm 1.4$ & 0.725 \\
\hline & TW $(J)$ & $263.8 \pm 33.9$ & $266.8 \pm 26.6$ & 0.451 \\
\hline
\end{tabular}

Results as Med \pm SE: $n=40$ : PT: peak torque BW: body weight, IPT: initial peak t rque, TW: total work 


\section{DISCUSSION}

Sex steroid hormone concentrations fluctuate during the menstrual cycle. Consequently, researchers argued that women's physical performance parameters could also fluctuate throughout the menstrual cycle $(20,21)$. Despite the long-lasting debate, existing literature does not provide a consensus on the issue. This is presumably partly due to the differences in methodologies across studies in terms of determining the phases of menstrual cycle and measuring performance (22).

Flexibility, dynamic balance, agility, vertical jump, aerobic capacity, anaerobic power, and isokinetic muscle strength in the early follicular and midluteal phases of the menstrual cycle were herein assessed. We found that the 'minimum power' value in Wingate test was higher during the midluteal phase. No other parameter was determined to be significantly different among different menstrual cycle phases.

Melegario et al. (23) used blood tests to determine menstrual cycle phases, and, did not find any significant phase-related differences ( $p>0.05$ ) for eight different flexibility movements in 20 women. Another study evaluated musculotendinous stiffness and knee joint laxity with KT20oo ${ }^{\mathrm{TM}}$ among 11 female netball players during early follicular, mid-follicular, ovulatory, and midluteal phases. The study did not reveal that estrogen fluctuations significantly influenced knee joint laxity ( $\mathrm{p}>0.05)$ (24).

Another study on 37 women assessed muscle stiffness by elastography and did not detect significant differences in resting muscle stiffness between different phases. However, this study reported significantly increased stiffness during contraction in the early follicular phase comparing to the ovulatory phase (25). In our study, we did not find that flexibility, as determined via the sit-and-reach test, differed significantly between different menstrual phases. Our results are consistent with the literature in that hormonal fluctuations did not clinically influence flexibility. High estrogen levels are known to cause collagen levels to decrease and fibroblast levels to be suppressed. Connective tissue laxity that results from this situation increases the risk of musculoskeletal injury 2-8 times compared men. Again, fluctuations in $17 \mathrm{~b}$-estradiol levels have been associated with injury risk, and this fluctuation may cause changes in tendon and muscle stiffness, increasing susceptibility to injury (25).

However, neither in this study nor in others where flexibility was evaluated, although small differences in flexibility between cycles were observed, they were not significant. In the literature examined, the number of subjects was always limited. In a study where a change in muscle stiffness was observed during contraction, muscle contractions were not evaluated quantitatively. Quantitative measurements of muscle stiffness are needed in broader studies, and during sports-specific movements in order to clearly demonstrate the relationship between the fluctuations in estrogen levels and injury.

In our review of the literature, we did not come across any study that examined the relationship between menstrual cycle phases and balance. Our results did not reveal an association between $\mathrm{Y}$ balance parameters and menstrual phases. Considering that studies do not report significant changes in muscle strength between phases $(18,19)$, it may be expected that balance would not be affected by hormonal changes, either. Unchanging flexibility may be another factor that is effective in unchanging balance performance.

Kheniser et al. (26) studied agility in early follicular and midluteal phases among 10 women. They determined ovulation using urine LH testing, and agility in the T-test and reactive agility test. They reported that in the T-test, the subjects were significantly faster during the early follicular phase, but that the two phases were not significantly different in terms of the reactive agility test. The authors attributed this finding to the fact that the reactive agility test requires cognitive function, which is not affected by the menstrual cycle, and that the altered joint laxity resulted in changed T-test results.

A different study investigated agility and edema in the gastrocnemius muscle through MRI in the early follicular, follicular, ovulatory, early luteal, and late luteal phases of $13 \mathrm{fe}$ male athletes. They reported significantly increased T2 signals in the early follicular phase compared to other phases $(p<0.01)$. They also found that agility decreased in the early follicular phase. These results were interpreted as indicating that agility decreases with increased fluid retention (27). In our study, we did not find a significant difference between agility results in early follicular and midluteal phases. We ascribe the inconsistency of our results with the literature to having used different test methods to evaluate agility and ovulation, and the small sample size. Further studies with larger samples are needed to conclusively demonstrate a relationship between agility and different menstrual phases.

In a study by Pisapia et al. (28), vertical jump performance was evaluated in the luteal and follicular phases, yielding no significant difference. In their study of 58 female athletes, Vrublevskiy et al. (29) found that jump performance was highest during the ovulatory phase and lowest during the early follicular phase. The results of these two studies 
are consistent. In our study, we found that different estrogen levels did not influence vertical jump performance. We predicted that there might be better vertical jumping performance in the mid-luteal phase, given the positive effects of high estrogen levels on the carbohydrate metabolism.

In another study, adolescent volleyball players were divided into two groups, and their vertical jumping performance was evaluated (30). Although estrogen levels were found to be statistically significantly higher in one group, no change was observed in vertical jumping performances. Considering these studies, we can comment that there is no significant relationship between estrogen level and vertical jumping performance, unlike our estimate. In addition, it should not to be forgotten that there are variations in hormonal changes between individuals, and seasonal ones, so each individual should be evaluated individually.

Numerous studies have examined the relationship between menstrual cycle and aerobic capacity, anaerobic power, and muscle strength. Minimal (2\%) decreases in aerobic capacity during the midluteal phase compared to the early follicular one is reported (29). In contrast, it is argued that progesterone can increase aerobic capacity due to increasing the respiratory rate during the midluteal phase (31). Studies investigating changes in lactate and ventilatory thresholds did not display changes in performance or threshold associations with menstrual cycle $(32,33)$. One study showed an increased ventilation threshold in the late follicular phase (32), whereas another reported that the $4.0 \mathrm{mmol} / 1$ lactate threshold occurred at a significantly higher exercise intensity in the luteal phase (33).

A review of 51 studies by McNuty et al. (4) concluded that aerobic capacity decreased minimally in the early follicular phase compared with other phases. They argued that conclusive evidence does not exist about exercise performance during the menstrual cycle due to the wide variation between studies. Our review of literature revealed multiple studies that concluded that aerobic capacity did not significantly change in different menstrual phases $(34,35)$. We did not find a significant change in aerobic capacity between the early follicular and midluteal phases.

In a study where the amount of glycogen in vastus lateralis biopsy material was evaluated, it was shown that the amount of intramuscular glycogen increased in the luteal phase, without contributing to aerobic performance (34). Again, it was shown in hamsters that the amount of uterine glycogen increased in the luteal phase that was not reflected in the muscle (34). When assessing studies in general, it is seen that even if the increased estrogen level increases the amount of intramuscular glycogen, this increase does not contribute to aerobic performance. Increased glycogen alo- ne does not seem to make sense independent of enzyme and cofactor levels required in substrate use. Thus, the relationship between menstrual cycle phases and anaerobic performance remains controversial (34).

A study by Arazi et al. (36) on 20 women aged 20-30 years did not reveal significant differences between Wingate test parameters in early follicular, ovulatory, and midluteal phases. Similarly, a study on 16 women did not display significant differences between anaerobic power results, as measured by a cycle ergometer, in the follicular and luteal menstrual phases (37). We found that 'minimum power' in the Wingate test was significantly higher during the midluteal phase. A review by McNuty et al. (3) stated that exercise performance minimally decreased during the early follicular phase. Estrogen is known to increase glucose uptake and maintain glycogen reserves. It can also act as an antioxidant and membrane stabilizer to attenuate inflammatory response (38). Moreover, estrogen may have neuro-stimulating effects that increase volitional activation. High estrogen levels in the midluteal phase may positively affect muscle performance and anaerobic power (3). Similarly, increased phosphocreatine and adenosine triphosphate reserves may be associated with better anaerobic performance in the luteal phase (34). These findings suggest that anaerobic power may change between the phases of the menstrual cycle.

Literature on the relationship between menstrual cycle phases and muscle strength is constantly growing. Janse de Jonge et al. (39) evaluated isokinetic knee flexion and extension muscle strengths in early follicular, late follicular, and luteal phases, and found no significant changes. Another study evaluated isokinetic knee flexor and extensor muscle strength ratios of 26 female athletes in the luteal and follicular phases. The hamstring-to-quadriceps muscle strength ratio was not different among phases in the dominant limb, but was significantly reduced during the follicular phase in the non-dominant limb $(\mathrm{p}=0.011)(40)$. A study by Fridén et al. (21) evaluated isokinetic knee extension and flexion muscle strength in early follicular, ovulatory, and midluteal phases in two consecutive menstrual cycles, and did not reveal significant changes in muscle strength between phases. In this study, we did not find a significant difference in isokinetic muscle strength parameters between the early follicular and midluteal phases. The variance of results in literature is partly ascribed to differences in isokinetic measurement methods, assessment parameters, and differences in evaluated menstrual cycle phases. Studies with comparable methodologies are required for more conclusive results. 
The heterogeneity of methodologies becomes obvious when reviewing the literature. Discrepancies concerning the investigated parameters and menstrual phases, sample sizes, and assessment methods can influence results, making it difficult to make comparative analysis. Regardless, the common finding is that different menstrual cycle phases do not significantly affect physical performance. However, it should not be forgotten that these small changes may causesignificant results in professional sports. The limitations of our study are not having included professional female athletes, and the small number of participants, which did not allow parametric testing in statistical analysis.

To conclude, physical performance is minimally affected by the different phases of menstrual cycle in the defined group. But, as tenths of a second can be critical in competitive sports, each female athlete still should be evaluated individually, and a personalized training program should be prepared, taking into account the menstrual cycle.

\section{Acknowledgments}

We would like to thank Prof. Dr. Ferdi Başkurt for their contributions in the design phase of the study and Res. Asst. Dr. Esma Arslan for their assistance in the data collection phase.

\section{Ethics Committee Approval / Etik Komite Onayı}

The approval for this study was obtained from Institutional Ethics Committee of Süleyman Demirel University, Isparta, Turkey (Decision no: 323 Date: 29/11/2019).

\section{Conflict of Interest / Çıkar Çatışması}

The authors declared no conflicts of interest with respect to authorship and/or publication of the article.

\section{Financial Disclosure / Finansal Destek}

The authors received no financial support for the research and/or publication of this article.

\section{Author Contributions / Yazar Katkıları}

Concept: SE, Design: SE, Supervision: CÇ, Materials: SE, Data Collection and/or Processing: AO, ME, TP, Analysis and İnterprepation: SE, Literature Review: AO, Writing Manuscript: AO, SE, Critical Reviews: All Authors.

\section{REFERENCES}

1. Fink JS. Female athletes, women's sport, and the sport media commercial complex: Have we really “come a long way, baby”? Sport Manag Rev. 2015;18(3):331-42.

2. IOC. Women in sport-history of female athletes participation. Available: https://www.olympic.org/women-in-sport/background. [cited 2020 Nov 16].

3. McNulty KL, Elliott-Sale KJ, Dolan E, Swinton PA, Ansdell P, Goodall S, et al. The effects of menstrual cycle phase on exercise performance in eumenorrheic women: a systematic review and meta-analysis. Sport Med. 2020;50(10):1813-27.

4. Dirk KL, Belfry GR, Heath M. Exercise and executive function during follicular and luteal menstrual cycle phases. Med Sci Sports Exerc. 2020;52(4):919-27.

5. Sung E, Han A, Hinrichs T, Vorgerd M, Manchado C, Platen P. Effects of follicular versus luteal phase-based strength training in young women. Springerplus. 2014;3(1):1-10.

6. Oosthuyse T, Bosch AN. The effect of the menstrual cycle on exercise metabolism. Sport Med. 2010;40(3):207-27.

7. Öztürk M. Üniversitede eğitim-öğretim gören öğrencilerde uluslararası fiziksel aktivite anketinin geçerliliği ve güvenirliği ve fiziksel aktivite düzeylerinin belirlenmesi. Hacettepe Üniversi tesi, Sağlık Bilimleri Enstitüsü, Fizik Tedavi ve Rehabilitasyon Programı Yüksek Lisans Tezi. Ankara: Hacettepe Üniversitesi, 2005.
8. Koroglu Medical. Product catalogue. Available: https://www.medicalmarket-ks. com/Articles/51/Images/26/o2/2018/915156_Koroglu_Medical_Devices_Ltd._Product_Catalogue_20122021 May 5].

9. Miller PB, Soules MR. The usefulness of a urinary LH kit for ovulation prediction during menstrual cycles of normal women. Obstet Gynecol. 1996;87(1):13-7.

10. Lohman TG, Milliken LA. ACSM's Body Composition Assessment. American College of Sports Medicine; 2019.

11. Carter JEL, Yuhasz MS. Skinfolds and body composition of olympic athletes. In: Carter JEL, Ed. Physical Structure of Olympic Athletes. Part II: Kinanthropometry of Olympic Athletes. Med Sport Sci Vol 18. Basel: Karger Publishers; 2015; pp. 14482.

12. Martin Moreno V, Gòmez Gandoy JB, Antoranz González MJ. Medicíon de la grasa corporal mediante impedancia bioeléctrica, pliegues cutáneos y ecuaciones a partir de medidas antropométricas. Análisis comparativo. Rev Esp Salud Publica. 2001;75(3):221-36.

13. Pense M, Serpek B. 14-16 yaş arası basketbol oynayan kız öğrencilerin fizyolojik ve biyomotorik özelliklerinin Eurofit test bataryası ile belirlenmesi. Selçuk Üniv Bed Ĕg Spor Bil Derg. 2010;12(3): 191-8.

14. Koçak UZ, Ünver B. Kadın futbolcularda yaralanma riski belirleyicileri olarak fonksiyonel hareket analizi ve Y denge testi arasındaki ilişkinin incelenmesi. Spor Hek Derg. 2019;54(1):1-8.

15. Beekhuizen KS, Davis MD, Kolber MJ, Cheng MSS. Test-retest reliability and minimal detectable change of the hexagon agility test. J Strength Cond Res. 2009;23(7):2167-71.

16. Cicioğlu İ, Gökdemir K, Erol E. Pliometrik antrenmanın 14-15 yaş grubu basketbolcuların dikey sıçrama performansı ile bazı fiziksel ve fizyolojik parametreleri üzerine etkisi. Spor Bilim Derg. 1996;7(1):11-23.

17. Mahar MT, Guerieri AM, Hanna MS, Kemble CD. Estimation of aerobic fitness from 20-m multistage shuttle run test performance. Am J Prev Med. 2011;41(4 Suppl 2):S117-23.

18. Bulgan Ç, Başar MA. Wingate anaerobik güç testi. Bulgan Ç, Başar MA, Çeviri editörleri. Insan Performansinda Fonksiyonel Testler (Reiman MP, Manske RC), 1. baskı. İstanbul: İstanbul Tip Kitabevleri; 2018. p. 266

19. Cvietkovic DD, Bijeliac S, Palija S, Talic G, Radulovic TN, Kosanovic MG et al. Isokinetic testing in evaluation rehabilitation outcome after acl reconstruction. Med Arch. 2015;69(1):21-3.

20. Gür H. Concentric and eccentric isokinetic measurements in knee muscles during the menstrual cycle: a special reference to reciprocal moment ratios. Arch Phys Med Rehabil. 1997;78(5):501-5.

21. Fridén C, Hirschberg AL, Saartok T. Muscle strength and endurance do not significantly vary across 3 phases of the menstrual cycle in moderately active premenopausal women. Clin J Sport Med. 2003;13(4):238-41.

22. Romero-Moraleda B, del Coso J, Gutiérrez-Hellín J, Ruiz-Moreno C, Grgic J, Lara B. The influence of the menstrual cycle on muscle strength and power performance. J Hum Kinet. 2019;68(1): 123-33.

23. Melegario SM, Simão R, Vale RGS, Batista LA, Novaes JdaS. The influence of the menstrual cycle on the flexibility in practitioners of gymnastics at fitness centers. Rev Bras Med Esporte. 2006;12(3): 125-8

24. Eiling E, Bryant AL, Petersen W, Murphy A, Hohmann E. Effects of menstrual-cycle hormone fluctuations on musculotendinous stiffness and knee joint laxity. Knee Surg Sports Traumatol Arthrosc. 2007;15(2):126-32.

25. Ham S, Kim S, Choi H, Lee Y, Lee H. Greater muscle stiffness during contraction at menstruation as measured by shear-wave elastography. Tohoku J Exp Med. 2020;250(4):207-13.

26. Kheniser KG. The effects of the menstrual cycle on agility. Cleveland State University, Department of Health and Human Performance, Master of Education in Exercise Science Degree Thesis, Cleveland; 2016.

27. Sawai A, Tochigi Y, Kavaliova N, Zaboronok A, Warashina Y, Mathis B], et al. MRI reveals menstrually-related muscle edema that negatively affects athletic agility in young women. PLoS One. 2018;13(1):1-13.

28. Pisapia F, Senatore B, Fattore S. Correlation between menstrual cycle and performance. $J$ Phys Educ Sport. 2019;19(Suppl5):1972-5.

29. Vrublevskiy E, Kozhedub M. The level of specific motor properties in the individual phases of the menstrual cycle among young sportswomen practicing sprints. Rocznik Lubuski. 2018;44(2a): 105-15

30. Kınıklı Gi, Harput G, Baltacı G, Çolakoğlu F. Farklı yaş gruplarındaki bayan adölesan voleybol oyuncularında izokinetik kas kuvveti, sıçrama performansı ve hormon seviyelerinin karşılaştıııması. Fizyoter Rehabil. 2013;24(1):17-25

31. Brutsaert TD, Spielvogel H, Caceres E, Araoz M, Chatterton RT, Vitzthum VJ. Effect of menstrual cycle phase on exercise performance of high-altitude native women at 3600 m. J Exp Biol. 2002; 205(2):233-9.

32. Dean TM, Perreault L, Mazzeo RS, Horton TJ. No effect of menstrual cycle phase on lactate threshold. J Appl Physiol (1985).2003;95(6):2537-43. 
33. Forsyth J, Reilly T. The combined effect of time of day and menstrual cycle on lactate threshold. Med Sci Sports Exerc. 2005;37(12):2046-53.

34. Štefanovský M, Péterová A, Vanderka M, Lengvarský L. Influence of selected phases of the menstrual cycle on performance in Special judo fitness test and Wingate test. Acta Gymnica. 2016;46(3):136-42.

35. Köse B. Analysis of the effect of menstrual cycle phases on aerobic-anaerobic capacity and muscle strength. J Educ Train Stud. 2018;6(8):23.

36. Arazi H, Nasiri S, Eghbali $\mathrm{E}$. Is there a difference toward strength, muscular endurance, anaerobic power and hormonal changes between the three phase of the menstrual cycle of active girls? Apunts Medicina Esport. 2019;54(202):65-72.

37. Wiecek M, Szymura J, Maciejczyk M, Cempla J, Szygula Z. Effect of sex and menstrual cycle in women on starting speed, anaerobic endurance and muscle power. Physiol Int. 2016;103(1):127-32
38. Ansdell P, Brownstein CG, Škarabot J, Hicks KM, Simoes DCM, Thomas K, et al. Menstrual cycle-associated modulations in neuromuscular function and fatigability of the knee extensors in eumenorrheic women. J Appl Physiol (1985).2019;126(6):1701-12.

39. Janse de Jonge XA, Boot CR, Thom JM, Ruell PA, Thompson MW. The influence of menstrual cycle phase on skeletal muscle contractile characteristics in humans. J Physiol. 2001;530(1):161-6.

40. Dos Santos Andrade M, Mascarin NC, Foster R, de Jármy di Bella ZI, Vancini RL, Barbosa de Lira CA. Is muscular strength balance influenced by menstrual cycle in female soccer players? J Sports Med Phys Fitness. 2017;57(6):859-64. 